
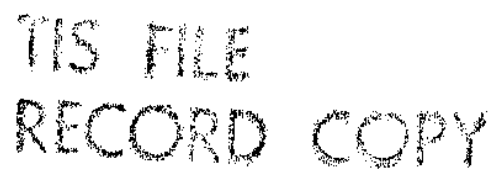

\title{
SEPARATION OF SRP WASTE SLUDGE AND SUPERNATE
}

\author{
J. A. STONE
}

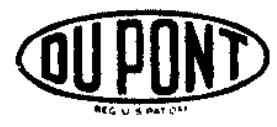

SAVANNAH RIVER LABORATORY AIKEN, SOUTH CAROLINA 29801 


\section{NOTICE}

This report was prepared as an account of work sponsored by the United States Government. Neither the United States nor the United States Energy Research and Development Administration, nor any of their contractors, subcontractors, or their employees, makes any warranty, express or implied, or assumes any legal liability or responsibility for the accuracy, completeness or usefulness of any information, apparatus, product or process diselosed, or represents that its use would not infringe privately owned rights.

Printed in the United States of America

Available from

National Technical Information Service

U. S. Department of Commerce

5285 Port Royal Road

Springfield, Virginia 22161

Price: Printed Copy \$4.00; Microfiche $\$ 2.25$ 


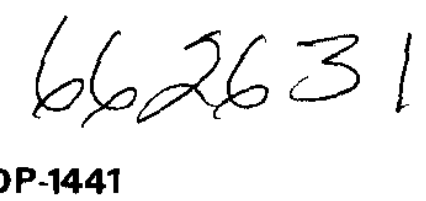

Distribution Category UC: 70

\section{SEPARATION OF SRP WASTE SLUDGE AND SUPERNATE}

by

J. A. Stone

Approved by

M. L. Hyder, Research Manager

Separations Chemistry Division

Publication Date: November 1976

E. I. DU PONT DE NEMOURS AND COMPANY

SAVANNAH RIVER LABORATORY

AIKEN, SOUTH CAROLINA 29801

PREPAREO FOR THE U. S. ENERGY RESEARCH AND DEVELOPMENT ADMINISTRATION UNDER CONTRACT AT(07.2).1 


\section{ABSTRACT}

Sludges and supernates were separated from Savannah River plant waste slurries by centrifugation and sand filtration. This separation, a portion of a conceptual process for solidification and long-term storage of high-level radioactive wastes, was tested in shielded cells with small-scale process equipment. Procedures for the separation were developed in tests with nonradioactive materials. Then, in 13 tests with actual sludges and supernates, solids removal ranged from 90 to 99.2 vol $\%$ and averaged 96.4 vol $\%$ after two passes through a basket-type centrifuge. Centrates from the tests, containing 0.05 to 0.2 vol : solids, were clarified by sand filter columns to produce solutions of the soluble salts with $<0.01$ vol $\%$ solids. About 700 liters of salt solution and 8 kilograms of washed, dried sludges were separated in the tests. Effects of sludge type, flocculant, flow rates, and batch size were evaluated. Washing and drying of centrifuged sludges were studied, and two types" of dryers were tested. Ruthenium volatility during drying was negligible. Washing efficiency was determined by analyses of wash solutions and sludge products. 


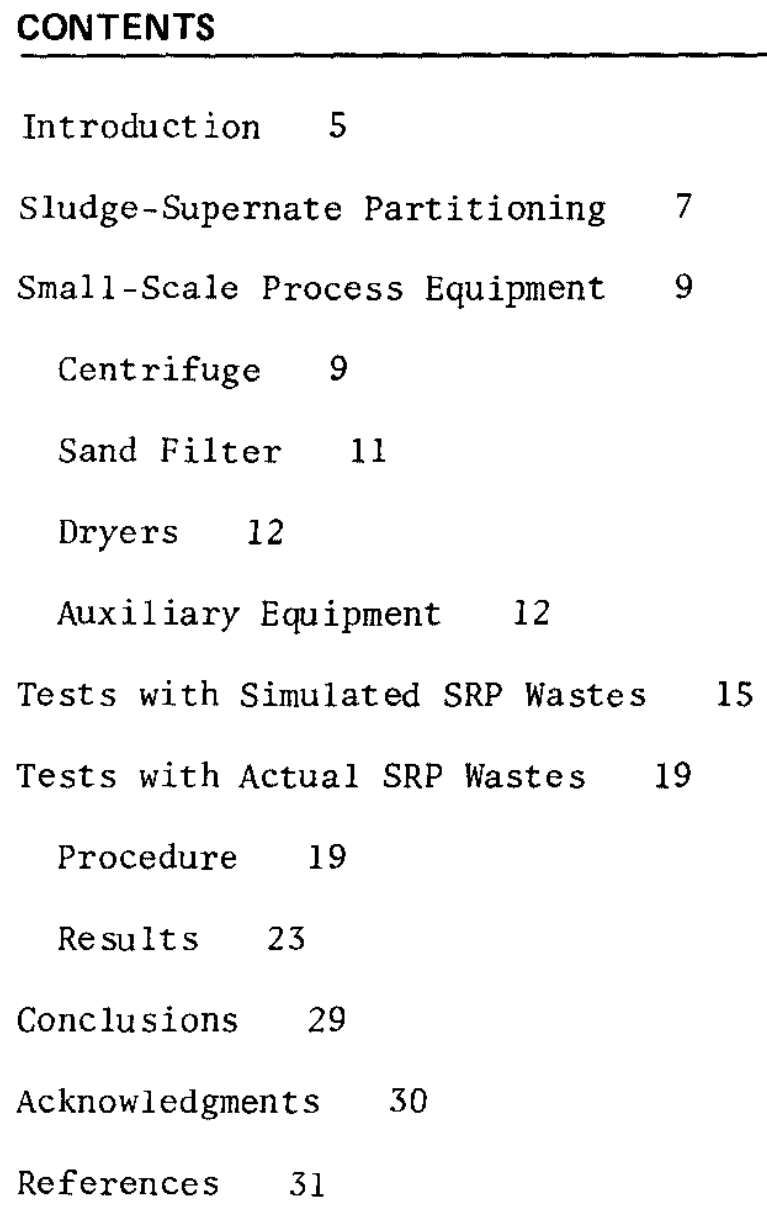




\section{LIST OF FIGURES}

1 Conceptual Process for Solidification of SRP High-Level Waste 6

2 Sludge-Supernate Partitioning Module 7

3 Top View of 12 -in. $(30.5 \mathrm{~cm})$ Basket Centrifuge 10

4 Sand Filter Columns 11

5 Centrifuge Bowl Dryer 13

6 Rotary Dryer 13

7 Equipment Arrangement for Operation in a Shielded Cell 15

8 Solids Removal in First-Pass Centrifugation of SRP Waste Slurries 25

\section{LIST OF TABLES}

1 Composition of Simulated Sludges 16

2 Composition of Simulated Supernate 16

3 Centrifuge Tests with Simulated Waste Slurries 17

4 Typical Analyses of Tank 15H Simulated Sludges and Washes 18

5 Adjusted Composition of Actual Supernates 19

6 Centrifuge Test Conditions with Actual Waste Slurries 20

7 Typical Centrifuge Test Data 24

8 Centrifuge Test Results with Actual Waste Slurries 26

9 Washed, Dried Sludges 27

10 Typical Analyses of Tank $15 \mathrm{H}$ Actual Sludges and washes 27

11 Principal Components of Washed, Dried Sludges 28 


\section{SEPARATION OF SRP WASTE SLUDGE AND SUPERNATE}

\section{INTRODUCT ION}

High-level radioactive wastes from operation of the Savannah River Plant (SRP) separations areas are made basic and stored in underground tanks. More than 20 million gallons (76 million liters) of high-level wastes are stored on the plantsite. A conceptual process for long-term management of these wastes has been proposed. ${ }^{1}$ The process would include removal of wastes from the tanks, solidification in either concrete or glass, and storage in a retrievable surface storage facility (RSF) until shipment to a federal repository.

The operations shown in Figure 1 have been designated as the conceptual process for development studies and cost estimates. The process is divided into seven independent major operations or modules, including:

1. Removal of waste from tanks. Sludge, supernate, and salt cake are slurried with recycled water; most of the salt cake dissolves. Development of Module 1 includes studies on wastetank cleaning that were made several years ago. ${ }^{2}$

2. Separation of sludge and supernate. A clarified salt solution containing most of the ${ }^{137} \mathrm{Cs}$ is produced. Solids are washed and dried to form sludge powder containing most of the ${ }^{90} \mathrm{Sr}$, other fission products, and plutonium. A small-scale process study on Module 2 is the subject of this report.

3. Separation of ${ }^{137} \mathrm{Cs}$ from supernate. The ${ }^{137} \mathrm{Cs}$ is removed by ion-exchange sorption and elution. The cesium eluate is then concentrated and fixed on zeolite. Decontaminated salt solution (effluent from cesium sorption step) is produced. Sma11-scale studies on Module 3 , reported separately, ${ }^{3}$ proceeded in conjunction with work on Module 2 .

4. Solidification of sludge and ${ }^{137} \mathrm{Cs}-z$ eolite. The conceptual process uses concrete as a matrix for immobilizing the powdered sludge and zeolite. Each concrete-waste casting is packaged in two containers. Glass has been proposed as an alternative to concrete as the solid waste form. Development studies on Module 4 have been made with both concrete ${ }^{4}$ and $\operatorname{glass}^{5,6}$ waste forms.

5. Evaporation of decontaminated salt solution produced in Module 3 . The solution is evaporated in wiped film evaporators, ${ }^{7}$ to yield monolithic salt that is packaged in single-walled containers. Evaporated water is used to slurry waste in the next tank. 
6. Storage of concrete waste forms. Canisters of solidified waste are stored in an RSF.

7. Storage of decontaminated salt cake. Packaged salt is stored in an RSF.

This report focuses on Module 2 of the conceptual process. Steps in the sludge-supernate separation are described in the following section. Tests were made with small-scale process equipment at full levels of radioactivity. The equipment and the test procedures are described. Results of the tests with both simulated and actual SRP waste provide a technical basis for design of a large-scale process.

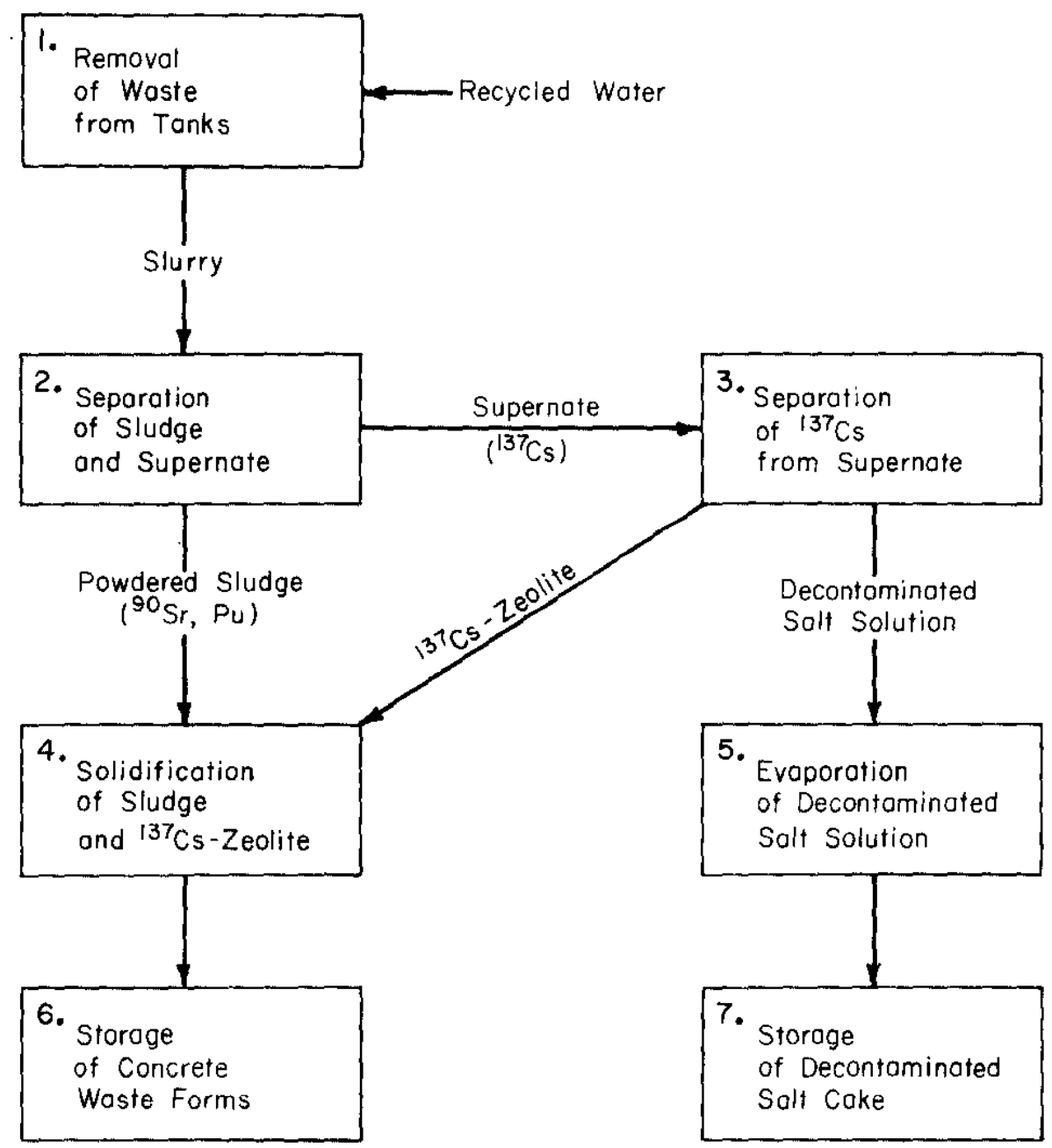

FIGURE 1. Conceptual Process for Solidification of SRP High-Level Waste 


\section{SLUDGE-SUPERNATE PARTITIONING}

Steps in the sludge-supernate separation module of the conceptual process are shown in more detail in Figure 2. The primary separation is made by centrifugation, which removes 295 vol $\%$ of the solids from the feed slurry. The remaining solids in the centrate are removed by sand filtration, which produces a clarified salt solution suitable for ion-exchange feed in the cesium removal module. Centrifuged sludge is dried, washed, and redried, to yield a powdered product for fixation in the solidification module. The conceptual process for large-scale operations is described below. Smal1-scale studies simulated parts of the process.

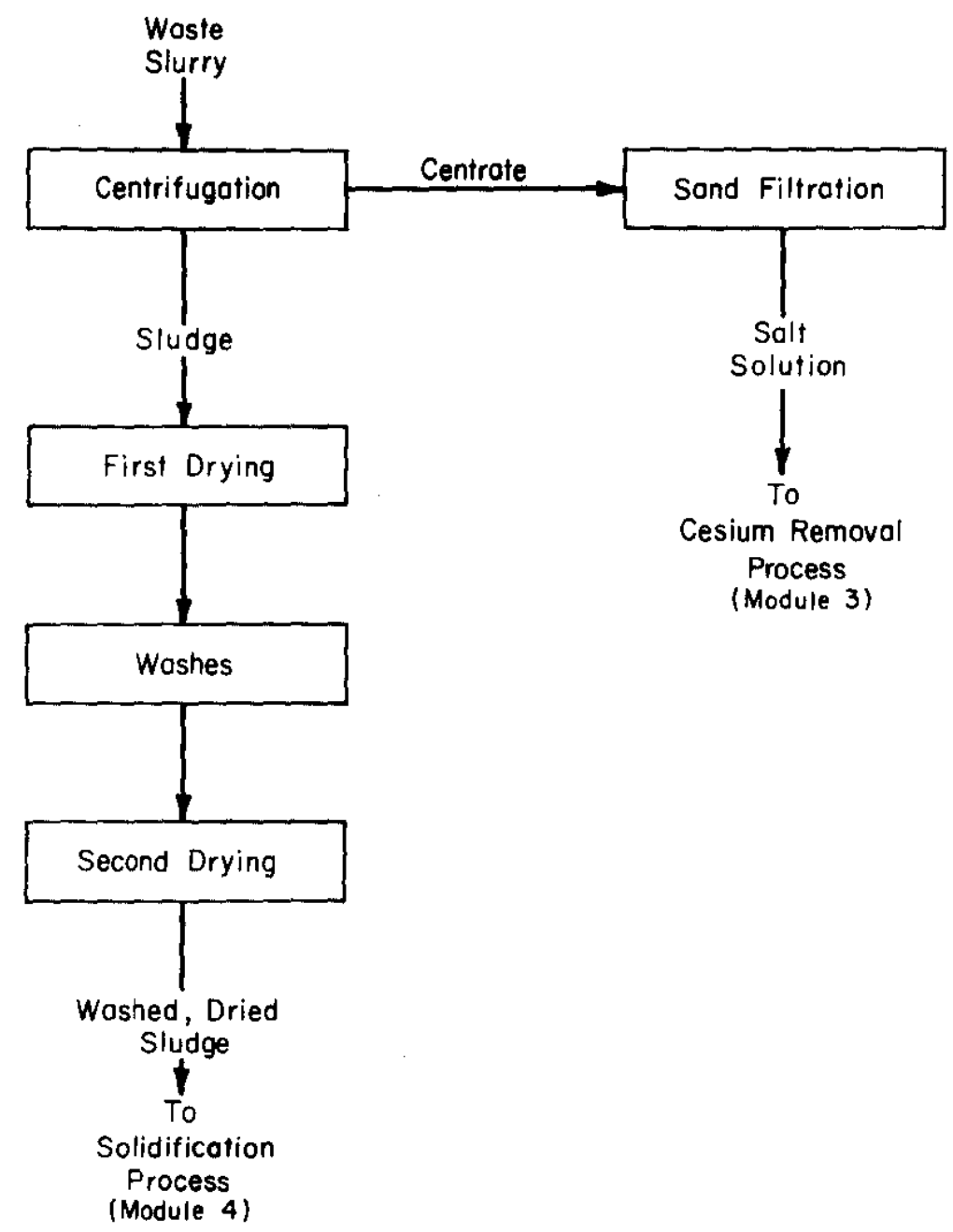

FIGURE 2. Sludge-Supernate Partitioning Module 
The conceptual process requires two stages of centrifugation for initial partitioning of the sludge and supernate. The first centrifuge, operating at a relatively fast feed rate, removes the bulk of the solids. The centrate from the first centrifuge feeds the second centrifuge at a slower rate to remove most of the remaining solids. Small streams of flocculating agent are fed concurrently with slurries to promote agglomeration of sludge particles and thereby increase separation efficiency. Centrifugation is done batchwise. After each batch is centrifuged the small amount of centrate 1 iquid remaining in a centrifuge is skimmed off.

For final clarification, the centrate is passed through a dual-media filter, usually referred to as a sand filter. Feed to the sand filter contains $\sim 5 \%$ of the solids in the original slurry. A small stream of flocculant is mixed with the feed near the top of the sand filter. At the end of each batch, the sand filter is backwashed to remove accumulated sludge particles, and the backwashes are returned to the first centrifuge feed for recycle. The filtrate from normal operation of the sand filter is clarified supernate containing soluble salts, ${ }^{137} \mathrm{Cs}$, and residual (minor) amounts of ${ }^{90} \mathrm{Sr}$ and plutonium.

Batches of wet sludge cake from centrifugation are washed and dried in typical large-scale process equipment, to remove the large mass $(60-80 \%)$ of soluble salts retained in the sludge. An initial drying is necessary to destroy the gelatinous properties of wet sludge. Two stages of washing are provided, in each of which the sludge is reslurried with water to dissolve soluble salts. Each stage consists of a washer and a centrifuge to remove spent wash-water for recycle. The washed sludge is dried in a second dryer, yielding a product containing nearly all of the ${ }^{90} \mathrm{Sr}$ and plutonium, and a residual amount of ${ }^{13}{ }^{7} \mathrm{Cs}$.

For the small-scale studies described in this report, emphasis was placed on obtaining process information on the centrifugation and sand filtration steps. Secondary goals were to provide clarified supernate for cesium-removal tests (Module 3 ), and to prepare washed, dried sludges for characterization and future solidification. Because these studies were not intended as a full demonstration of the entire module, several departures from conceptual process conditions were made. For example, the primary sludge-supernate separation was performed by two passes through a single small-scale centrifuge, rather than using two centrifuges in series. Sludge washing and drying operations were by methods that were convenient on the small scale, and did not simulate the large-scale unit operations. 
A number of process effects and parameters were investigated in the tests. These included:

- Sludges from different waste tanks and areas

- Various flow rates for slurry and flocculant

- Elimination of flocculant

- Various batch sizes

- Sand filter efficiency

- Various drying techniques

- Ruthenium volatility during sludge drying

- Sludge washing efficiency

- Yields of sludge products

The tests were performed with sma11-scale process equipment described in the following section.

\section{SMALL-SCALE PROCESS EQUIPMENT}

Several pieces of equipment for small-scale sludge-supernate separations were modified for remote operation and assembled into an operating system in the shielded cell facilities at the Savannah River Laboratory (SRL). The system included a basket-type centrifuge and a sand filter similar to those proposed for largescale operation. In addition, two types of dryers were tested. Various auxiliary equipment, such as pumps, flowmeters, and tanks, completed the system.

\section{Centrifuge}

A top view of the smal1-scale centrifuge (De Laval Separator Co., Hyde Park, Mass.) is shown in Figure 3. The basket-type stainless-steel bow 1 is 12 in. $(30.5 \mathrm{~cm})$ in diameter by $5.5 \mathrm{in}$. (14 cm) high. The solid bowl is mounted on a resilient spindle that is belt-driven by an electric motor. The speed of rotation may be adjusted by varying the tension on the drive belt. For the tests described in this report the centrifuge was operated at $2750 \mathrm{rpm}$ or about $1300 \mathrm{G}$, to simulate the centrifugal force in a production-size machine. Bowls are interchangeable and are attached by a single nut for ease of removal. Other features of the centrifuge, not shown in Figure 3, are a cover plate, a linear skimmer, and a brake. 
During centrifugation, a sluxry is fed into the rotating centrifuge bowl at a point about midway between the center and outer rim. Solids are forced to the inmer wall of the bowl. liquide is also thrown unifomly to the wall, eventually filling the bowl, overtowing into the stainless-steel curb, and emerging as contrate from an outlet pipe. After the startup period during which the bow fills, sludge-supernate sepaxation depends upon residence time in the bowl, and thus upon the feed rate. In principle the separation could continue until the thickness of the solids cake reached the lip of the bowl. However, solids contents of batches used in the present tests were much below this limiting value. To teminate a separation, the excess liquid between the bowl lip and the cake is skimmed from the rotating bowl.

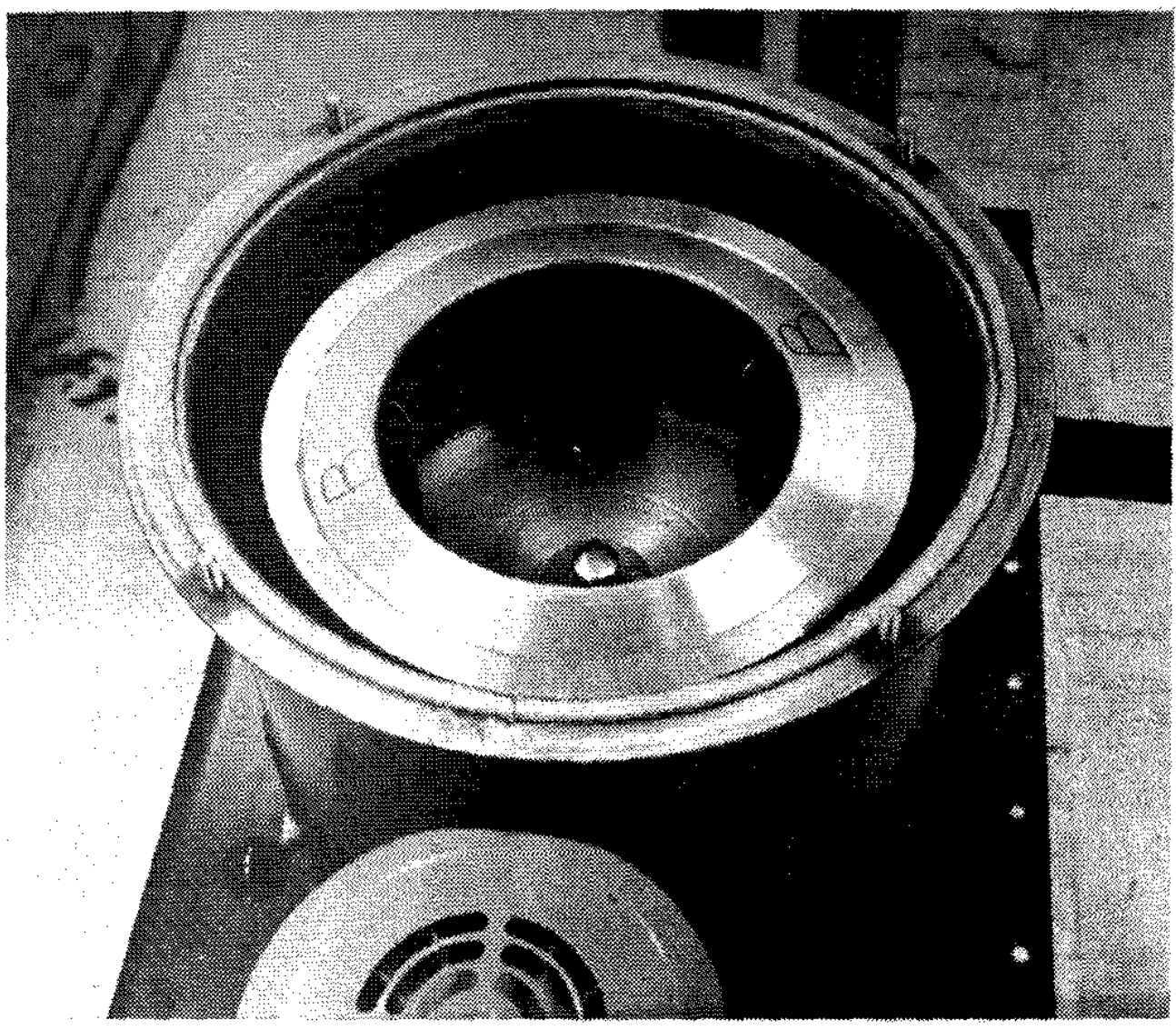

FlGURE 3. Top View of $12-\mathrm{in} .(30.5 \mathrm{~cm})$ Basket Centrifuge 
The centrifuge and bowl were also useful for washing and drying sludge. In one method of drying, the bowl containing wet sludge cake was placed in a heater to dry, eliminating a difficult sludge unloading step. The sludge was also washed in the centrifuge bowl. With the bowl stationary in the centrifuge, wash water was added, and the cake was reslurried with a stirrex; after the slurry was stirred for one hour, the centrifuge was started to separate the washed solids from the liquid, which was removed by skimming.

\section{Sand Filter}

The sand filter consists of two stainless-steel columns in series (Figure 4), filled with finely graded sand and anthracite coal. Each column is 4 in. $(10.2 \mathrm{~cm})$ in diameter by $51 \mathrm{in.}(129.5$ cm) long, with the filter bed composed of $24 \mathrm{in.}(61 \mathrm{~cm})$ of sand and $8 \mathrm{in}$. $(20.3 \mathrm{~cm})$ of coa 1 . Piping, valves, and pressure gauges are provided for operating and for backwashing the sand filter in
various ways.

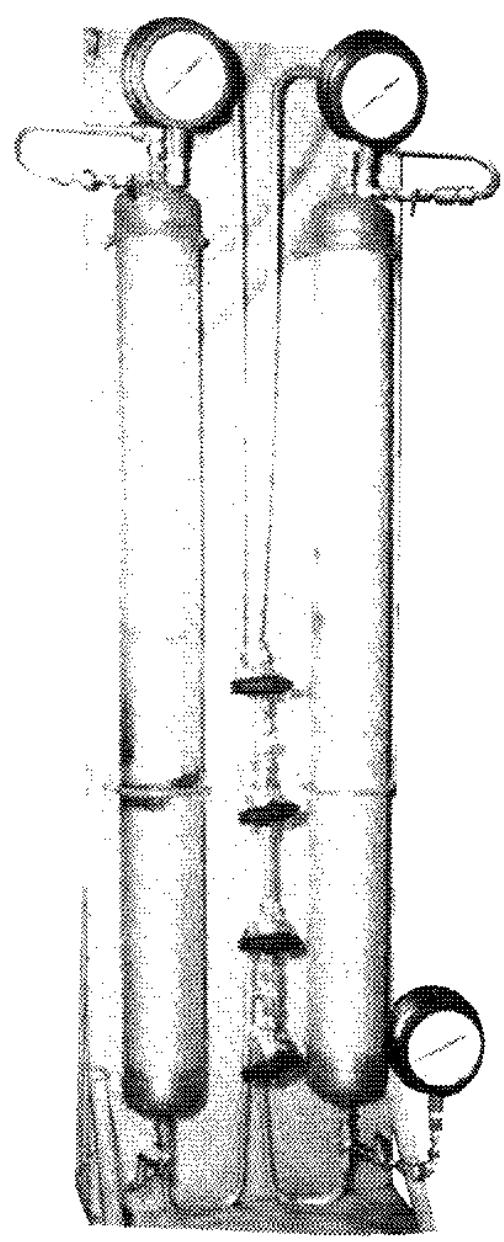

FIGURE 4.

Sand Filter Columns 
For the small-scale studies, the sand filter was operated batchwise. Centrate was pumped through the sand filter at 400 $\mathrm{ml} / \mathrm{min}$, and flocculant was fed at $20 \mathrm{ml} / \mathrm{min}$. The filtrate was stored for subsequent use in cesium-removal studies. After each batch, the sand filter was backwashed with water at $101 / \mathrm{min}$ for 4 minutes to remove accumulated sludge particles.

\section{Dryers}

Two types of sludge dryers were tested for smal1-scale batch operations. An oven-like heater for direct drying of sludges in a centrifuge bowl was used in most tests. A semicontinuous rotary dryer was also developed.

Figure 5 shows the centrifuge bowl dryer. A simple container holds a band heater and insulation around the wall, and the floor is covered with firebrick material. Evaporated water and other gases flow through a lid to the offgas system. Temperature is measured by metal themometers inserted through the lid and in the air gap between heater and bowl. With this arrangement, a batch of sludge typically can be dried in 16 to 24 hours at $140^{\circ} \mathrm{C}$. After sludge and bowl cool, they can be returned to the centrifuge for washing, or dried product can be scraped from the bow 1 .

Figure 6 shows the rotary dryer, which consists of heated rotating drums fed with wet sludge forced from a hydraulic chamber. The sludge is spread uniformly into a thin film by being squeezed between the two drums. The film of sludge dries quickly and is scraped off the slowly rotating drum after a half rotation. A batch of sludge can be dried in about two hours. With the rotary dryer, wet sludge must be transferred from the centrifuge bowl to the hydraulic chamber.

\section{Auxiliary Equipment}

Other equipment used in the small-scale separations of sludge and supernate included four pumps to handle various liquid streams, a magnetic flowmeter for measuring slurry flow rates to the centrifuge, two 70-1iter tanks for feed and centrate, and a high-speed test-tube centrifuge for measuring solids content of slurry samples. 


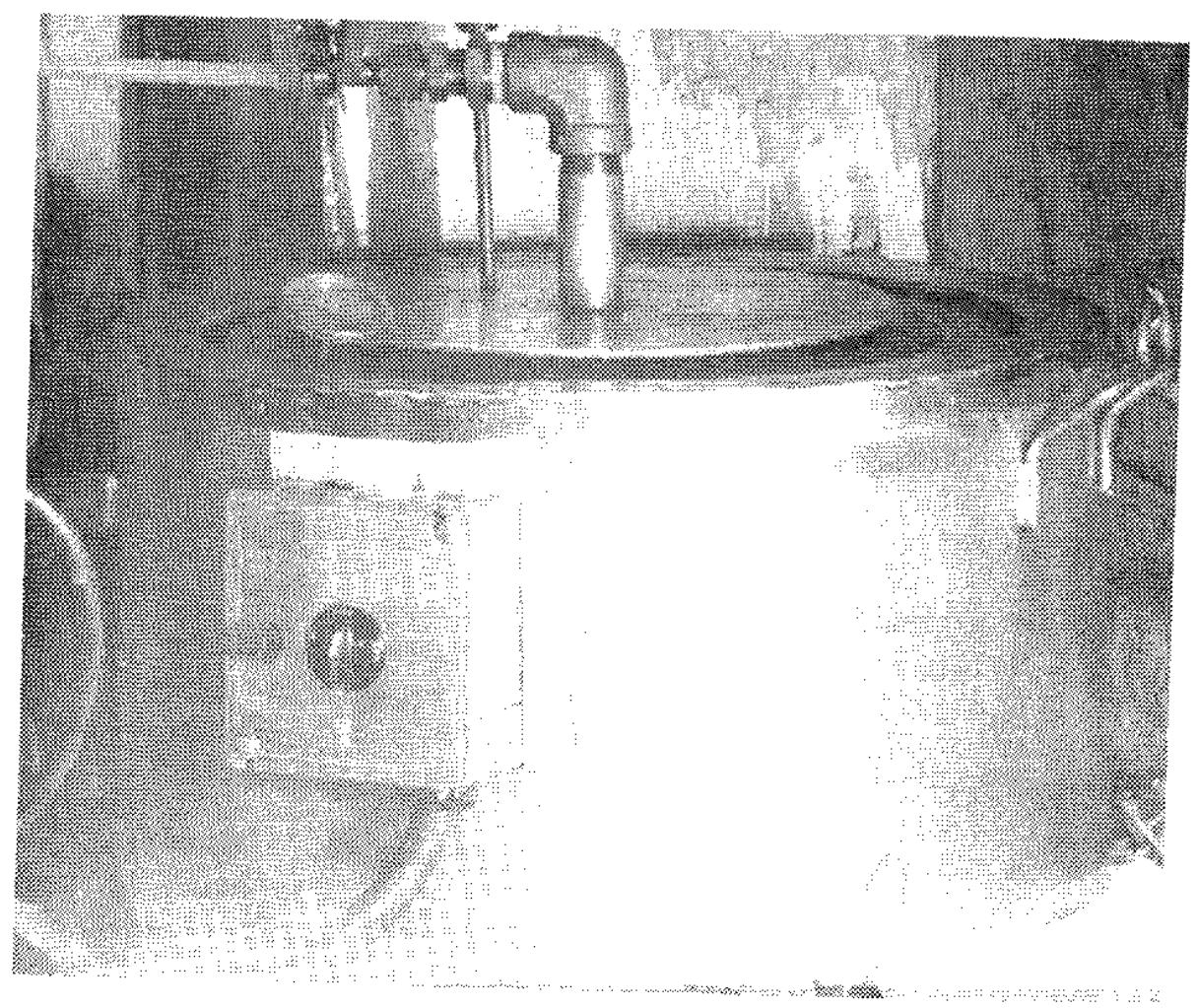

FrOURE 5. Centrifuge Bow Dryer

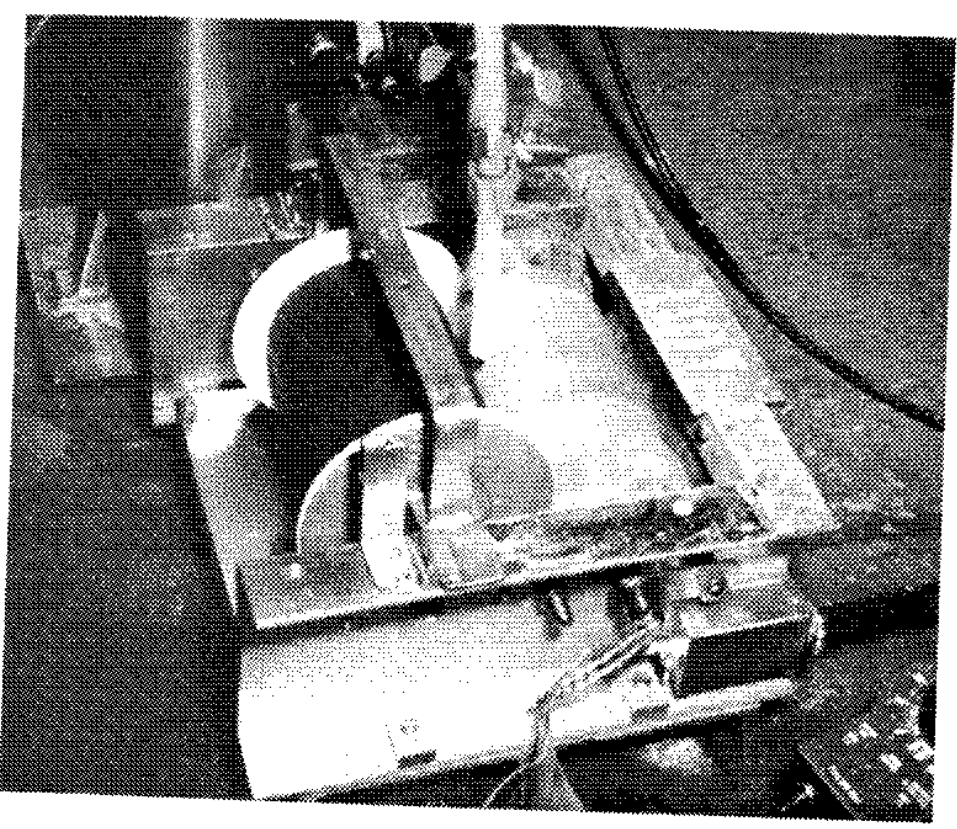

FIGURE 6. Rotary Dryer 
Slurries of waste were fed to the centrifuge and transferred between the two tanks by a stainless-steel centrifugal pump (Sethco Manufacturing Co., Freeport, NY). The slurry pump has a double stuffing box with graphite asbestos packing. The seals are cooled by an external water line arranged to permit small leakage into the seals, rather than outward. The pump provides flow rates up to $81 / \mathrm{min}$ in the test system, while simultaneously recirculating the remaining slurry to prevent settling.

Flocculant was fed to the centrifuge with a variable-speed tubing pump (Cole-Parmer Instrument Co., Chicago, I11.). Flow rates from 70 to $490 \mathrm{~m} 1 / \mathrm{min}$ were measured by precalibrating the pump speed control with the solution to be pumped.

Centrate and flocculant were fed to the sand filter with two small bellows pumps (Gorman-Rupp Industries, Bellville, Ohio). Centrate was fed at $400 \mathrm{ml} / \mathrm{min}$ by a pump incorporating a 1.5 -in. $(3.8 \mathrm{~cm})$ bellows, and flocculant was fed at $20 \mathrm{ml} / \mathrm{min}$ by a pump with a $0.5-$ in. $(1.3 \mathrm{~cm})$ bellows.

A magnetic flowmeter with stainless steel tube, flanges, and float (Wallace \& Tiernan, Belleville, NJ) measured slurry feed rates to the centrifuge. An ordinary rotameter-type flowmeter would have been undesirable for this application because of difficulty in reading with the darkly colored slurries. The magnetic flowmeter was precalibrated with slurries over the range 0 to $7.6 \mathrm{I} / \mathrm{min}$.

Tanks for feed slurry and centrate were cylindrical 70-1iter stainless steel vessels, open at the top. Volume of liquid in a tank was indicated by a calibrated wooden rod attached to a float.

Figure 7 shows the centrifuge and some of the auxiliary equipment in a mock-up cell, with the same arrangement later used in a shielded cell. The slurry pump, magnetic flowmeter, and 70-1iter tanks are shown. Movable inlet and outlet lines for the slurry pump provided operating flexibility with a single pump.

Solids in samples of feed slurries and centrate streams were measured with a small high-speed centrifuge (De Laval Separator Co., Poughkeepsie, N.Y.). Calibrated centrifuge cones with capillary tips were used to measure solids contents down to 0.01 volume $\%$. With on $1 y$ minor modifications, this centrifuge was operated remotely for routine solids deteminations in a shielded cell. 


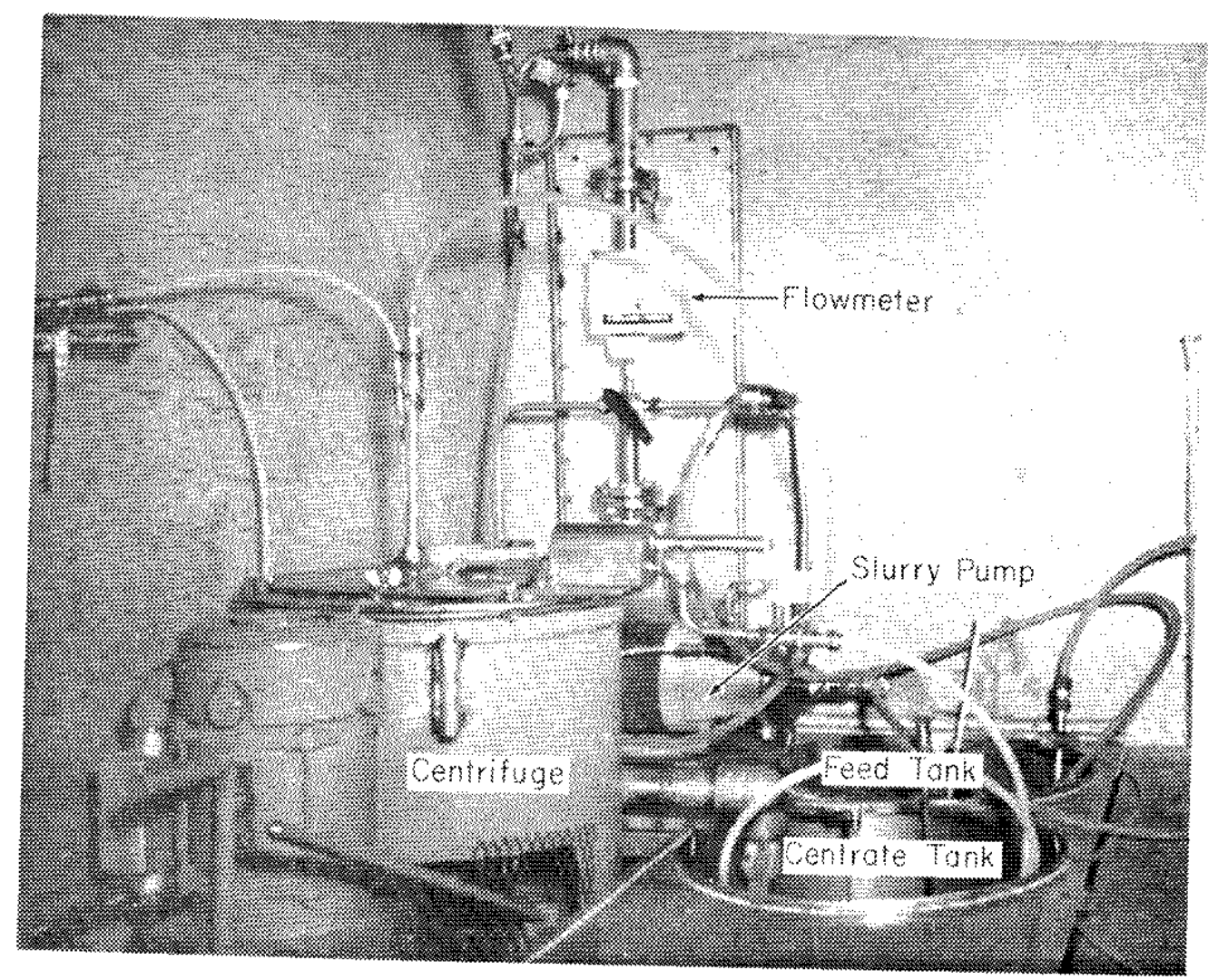
FCURE 7. Equipment Arrangement for operation in a
Shielded Cell

\section{TESTS WTH SHMUARE SRP WASTES}

Several components and operations of the sludgemsupernate partitiong rodule were tested wh simulated (ronradioactive) wastos borore remote prerations were perfomed in a shelded dati Contrifuge tests whth simulated waste slurries provided and arying procodures weresults for actual wastes. Washing products fron some of the tests.

About 200 liters of each of thee types of slumies were prepared for tests on simulated waste. The sludge components simulated the chemical compositions of sludges in three SRP waste tanks." Each sludge contaned the hydrous oxides of five procepal olements of the actual sludge, as shown in table 1 . provionsty previously, The sludges were slurwed with a simulated super-
nate (Table 2 ) to givens vol solids in each. 


\section{TABLE 1}

Composition of Simulated Sludges, mole \%

Tank $5 F$ Tank $13 H$ Tank $15 \mathrm{H}$

$\begin{array}{llll}\mathrm{Fe} & 58 & 50 & 4 \\ \mathrm{Mn} & 23 & 16 & 3 \\ \mathrm{Al} & 7 & 27 & 92 \\ \mathrm{Ca} & 2 & 6 & 0.5 \\ \mathrm{Ni} & 10 & 1 & 0.5\end{array}$

TABLE 2

Composition of Simulated Supernate

Salt Concentration, $M$

$\mathrm{NaNO}_{3} \quad 2.60$

$\mathrm{NaNO}_{2} \quad 1.45$

$\mathrm{Na}_{2} \mathrm{SO}_{4} \quad 0.40$

$\mathrm{Na}_{2} \mathrm{CO}_{3} \quad 0.40$

Three centrifuge tests with each type of slurry were made with procedures to be used for actual wastes. Some refinement of the procedures (given in the following section) was possible as the tests progressed. In a centrifuge test, 50 liters of slurry were passed through the centrifuge two or three times under different conditions of feed rate and flocculant usage. With each sludge, the first test was without flocculant; a relatively slow feed rate of $2.21 / \mathrm{min}$ was used for three passes (two with Tank $15 \mathrm{H}$ sludge). The second test also had slurry feed rates of $2.21 / \mathrm{min}$ for two passes, but with flocculant (Betz 1100) fed at $140 \mathrm{ml} / \mathrm{min}$ for the first pass and $70 \mathrm{ml} / \mathrm{min}$ for the second pass. In the third test, the slurry feed rate for the first pass was increased to $6.21 / \mathrm{min}$ with flocculant at $470 \mathrm{mI} / \mathrm{min}$; conditions for the second pass were the same as for the preceding test, $2.2 \mathrm{l} / \mathrm{min}$ for slurry and $70 \mathrm{~m} 1 / \mathrm{min}$ for flocculant. 
The separations achieved in the nine centrifuge tests with simulated waste slurries are shown in Table 3 . For each test the cumulative solids removal for each pass is shown. In all tests but one, $>95$ vol $\%$ of the solids were removed from the final centrates: Comparison of tests with and without flocculant shows that good separations were achieved either way; these data give 1ittle evidence of beneficial effects from flocculant. Slurries of simulated Tank $5 \mathrm{~F}$ and Tank $15 \mathrm{H}$ wastes were separated better than were slurries of simulated Tank $13 \mathrm{H}$ waste. A third pass improved the separation of Tank $13 \mathrm{H}$ slurry, but not the other two separations. As expected, the high feed rate for the first pass removed fewer solids than did the slow feed rate; however, the second pass at the slow feed rate gave satisfactory cumulative results.

Mechanical effects in the centrifuge strongly affected the degree of separation. Experiments prior to installation in the shielded cell showed that spindle type, bow1 balance, and leveling of the centrifuge were important for proper operation. A rigid spindle originally installed in the centrifuge caused excessive vibration above $1800 \mathrm{rpm}$, but substitution of a resilient spindle produced satisfactory operation. Centrifuge bowls, although interchangeable, were not identical in balance, thus affecting performance at the operating speed. If the centrifuge was not sufficiently level, two effects occurred: a) liquid-solid separation would cease because of an oscillatory motion of the bowl, and $b$ ) excessive forces on the spindle would cause bearings to wear out prematurely. With proper leveling and balancing, the centrifuge separated slurries satisfactorily.

\section{TABLE 3}

Centrifuge Tests with Simulated Waste Slurries

\begin{tabular}{|c|c|c|c|c|c|c|}
\hline \multirow[b]{3}{*}{ Test } & \multirow{3}{*}{$\begin{array}{l}\text { Centrifuge } \\
\text { Pass }\end{array}$} & & & \multicolumn{3}{|c|}{$\begin{array}{l}\text { Cumulative solids } \\
\text { Removal, vol } \%\end{array}$} \\
\hline & & \multicolumn{2}{|c|}{ Flow Rate, $1 / \mathrm{min}$} & Tank & Tank & Tank \\
\hline & & szurry & Eloceulant & $5 F$ & $13 \mathrm{H}$ & $15 \mathrm{H}$ \\
\hline \multirow[t]{3}{*}{ A } & 1 & 2.2 & 0 & 98 & 80 & 98 \\
\hline & 2 & 2.2 & 0 & 98 & 93 & 98 \\
\hline & 3 & 2.2 & 0 & 99 & 96 & - \\
\hline \multirow[t]{2}{*}{ B } & 1 & 2.2 & 0.14 & 98 & 87 & 96 \\
\hline & 2 & 2.2 & 0.07 & 98 & 95 & 98 \\
\hline \multirow[t]{2}{*}{ C } & 1 & 6.2 & 0.47 & 75 & 75 & 92 \\
\hline & 2 & 2.2 & 0.07 & 95 & 93 & 97 \\
\hline
\end{tabular}


Sludge drying methods were investigated in preliminary experiments with nonradioactive sludges separated during the centrifuge tests. In-bowl drying was tested by heating a centrifuge bowl containing wet sludge cake at $140^{\circ} \mathrm{C}$ overnight in a laboratory oven. The sludge dried satisfactorily, and heating did not harm the bowl. These drying tests led to development of the bowl dryer shown in Figure 5.

For convenience in remote operations, a method of washing sludge in the bowl, while it is mounted in the centrifuge, was developed using sludges from four centrifuge tests. Samples of the sludge and washes were analyzed ${ }^{10}$ for $\mathrm{Na}^{+}, \mathrm{NO}_{3}{ }^{-}, \mathrm{NO}_{2}{ }^{-}$, and $\mathrm{SO}_{4}{ }^{2-}$, to determine washing efficiency. The washes also were analyzed for $\mathrm{CO}_{3}{ }^{2-}$ and $\mathrm{Al}(\mathrm{OH})_{4}{ }^{-}$. Some typical results are given in Table 4 , where material balances reflect analytical uncertainties. Three washes of $\sim 4$ liters each were judged satisfactory for the simulated sludges.

The sand filter was tested once with centrate from a centrifuge test with simulated waste slurry. Filtration and backwashing behavior were satisfactory. Most of the development was done with earlier models of the sand filter.

TABLE 4

Typical Analyses of Tank 15H SimuTated Sludges and Washes

\begin{tabular}{|c|c|c|c|c|c|c|c|}
\hline & & $\mathrm{Na}^{+}$ & & & $\mathrm{NO}_{3}{ }^{-}$ & & \\
\hline & Quantity & Conc & Moles & Groms & Cone & Molea & Grams \\
\hline Unwashed Sludge & $762 \mathrm{~g}$ & 24.0 wt $\%$ & 7.95 & 183 & 33.8 wt $\%$ & 4.16 & 258 \\
\hline \multicolumn{8}{|l|}{ Washes: } \\
\hline First & 3.34 & $1.45 \mathrm{M}$ & 4.84 & 111 & $0.742 \mathrm{M}$ & 2.48 & 154 \\
\hline Second & 3.60 & $0.39 \mathrm{M}$ & 1.40 & 32 & $0.189 \mathrm{M}$ & 0.68 & 42 \\
\hline Third & 3.68 & $0.10 \mathrm{M}$ & 0.36 & 8 & $0.050 \mathrm{M}$ & 0.18 & 11 \\
\hline Total & 10.62 Iiters & & 6.60 & 151 & & 3.34 & 207 \\
\hline Product Sludge & $97 \mathrm{~g}$ & 11.1 wt $\%$ & 0.47 & 11 & 2.7 wt $\frac{q}{6}$ & 0.04 & 3 \\
\hline
\end{tabular}




\section{TESTS WITH ACTUAL SRP WASTES}

\section{Procedure}

Sixteen 3-1iter batches of high-level waste sludges were collected from seven SRP waste tanks, by methods developed in an earlier sampling campaign. ${ }^{8}$ Sludges were obtained from Tanks 4, 5, and 6 in F Area, and Tanks 12,13, 15, and 16 in $\mathrm{H}$ Area. Waste supernates were obtained in 40-1iter batches ${ }^{3}$ from Tanks $15 \mathrm{H}$ and $34 \mathrm{~F}$. Waste slurries were reconstituted from sludge, supernate, and nonradioactive chemicals added to adjust concentrations to conditions specified in the conceptual process. The supernate concentrations after adjustment are given in Table 5; generally, the supernates were diluted to reduce $\mathrm{OH}^{-}$ concentration to the desired value, and appropriate quantities of the other salts were added. ${ }^{3}$ From these sludge and supernate batches, 13 centrifuge tests were made, and the liquids and solids from the tests were further processed to yield clarified salt solution and washed, dried sludge powder. Conditions for the 13 tests are given in Table 6. A general procedure, used with occasional variations in all the tests, is given below. All operations with radioactive waste slurries were performed in shielded cells.

\section{TABLE 5}

Adjusted Composition of Actual Supernates

$$
\text { Concentration, } M
$$

$\begin{array}{ll}\mathrm{NaAlO}_{2} & 0.50 \\ \mathrm{NaOH} & 0.75 \\ \mathrm{NaNO}_{3} & 2.2 \\ \mathrm{NaNO}_{2} & 1.1 \\ \mathrm{Na}_{2} \mathrm{SO}_{4} & 0.3 \\ \mathrm{Na}_{2} \mathrm{CO}_{3} & 0.3 \\ \mathrm{CsNO}_{3} & 0.0002\end{array}$


TABLE 6

Centrifuge Test Conditions with Actual Waste Siurries

\begin{tabular}{|c|c|c|c|c|c|c|}
\hline \multirow[b]{3}{*}{ Test } & \multirow[b]{3}{*}{ Tank } & \multicolumn{4}{|c|}{ Flow Rate, $1 / \mathrm{min}$} & \multirow{3}{*}{$\begin{array}{l}\text { Carrier } \\
\text { Precipitant }\end{array}$} \\
\hline & & \multicolumn{2}{|c|}{ First Pass } & \multicolumn{2}{|c|}{ Second Pass } & \\
\hline & & slurry & Flocculant & sturry & Flocoulant & \\
\hline 1 & $13 \mathrm{H}$ & 1.9 & 0 & 1.9 & 0 & None \\
\hline 2 & $13 \mathrm{H}$ & 1.9 & 0.14 & 1.9 & 0.07 & $\mathrm{Sr}_{3}\left(\mathrm{PO}_{4}\right)_{2}$ \\
\hline 3 & $13 \mathrm{H}$ & 6.6 & 0.49 & 1.9 & 0.07 & $\mathrm{Sr}_{3}\left(\mathrm{PO}_{4}\right)_{2}$ \\
\hline 4 & $5 \mathrm{~F}$ & 1.9 & 0 & 1.9 & 0 & $\mathrm{Sr}_{3}\left(\mathrm{PO}_{4}\right)_{2}$ \\
\hline 5 & $5 F$ & 1.9 & 0.14 & 1.9 & 0.07 & $\mathrm{Sr}_{3}\left(\mathrm{PO}_{4}\right)_{2}$ \\
\hline 6 & $5 \mathrm{~F}$ & 6.6 & 0.49 & 1.9 & 0.07 & $\mathrm{Sr}_{3}\left(\mathrm{PO}_{4}\right)_{2}$ \\
\hline 7 & $4 F, 6 F^{a}$ & 4.7 & 0.35 & 1.9 & 0.07 & $\mathrm{Sr}_{3}\left(\mathrm{PO}_{4}\right)_{2}$ \\
\hline 8 & $15 \mathrm{H}$ & 3.8 & 0.28 & 1.9 & 0.07 & None \\
\hline \multirow[t]{2}{*}{9} & $15 \mathrm{H}$ & 3.8 & $0^{b}$ & & & \\
\hline & & 3.8 & 0.28 & 1.9 & 0.07 & $\mathrm{Sr}_{3}\left(\mathrm{PO}_{4}\right)_{2}$ \\
\hline 10 & $16 \mathrm{H}$ & 5.7 & 0.42 & 1.9 & 0.07 & $\mathrm{FeCl}_{3}$ \\
\hline \multirow[t]{2}{*}{11} & $16 \mathrm{H}$ & 5.7 & $0^{b}$ & & & \\
\hline & & 5.7 & 0.42 & 1.9 & 0.07 & $\mathrm{Zr} \mathrm{O}_{2} \cdot \mathrm{xH}_{2} \mathrm{O}$ \\
\hline 12 & $12 \mathrm{H}$ & 7.6 & 0.49 & 1.9 & 0.07 & $\mathrm{CaCO}_{3}+\mathrm{FeCl}_{3}$ \\
\hline 13 & $12 \mathrm{H}$ & 1.9 & 0.07 & 1.9 & 0.07 & None \\
\hline
\end{tabular}

a. Double batch.

b. Reslurried after preliminary pass with no flocculant.

\section{Feed Preparation}

Waste slurry for centrifuge feed was prepared by mixing measured quantities of actual sludge, simulated supernate, and actual supernate in the feed tank. The mixture was allowed to stand overnight to permit additional solids to precipitate. Typically, 3 liters of SRP sludge was mixed with supernate to give 50 liters of slurry. Prior to a centrifuge test the slurry was agitated for one hour with the slurry pump operating in the recirculation mode, to simulate the shearing action of waste tank slurry pumps. The slurry was then sampled and measured for solids content. 


\section{FZocculant Preparation}

Flocculant solution (1000 ppm) was prepared in 10-liter batches, no earlier than one day before a centrifuge test. 10.0 $g$ of solid flocculant (Betz 1100) was slurried in a small volume of isopropyl alcohol and added to 23.5 liters of water in a beaker. The mixture was heated at $250^{\circ} \mathrm{C}$ with gentle stirring for 4 hours, to give a clear solution. After cooling, the solution was transferred to a bottle and diluted to 10 1iters. Flocculant solution was fed to the centrifuge with a tubing pump, from outside the shielded cell.

\section{Centrifugation}

A centrifuge test started with the bowl empty and rotating at full speed. The flocculant flow was started, immediately followed by feed (slurry) flow, at measured flow rates. Centrate was collected in the centrate tank. A sample was taken from the centrate stream after each 10 liters of centrate was collected, as determined by timed intervals. When the feed tank was empty, the flocculant flow was stopped. Residual liquid in the centrifuge bowl was removed by skimming into a calibrated glass bottle; typically, 2 to 4 liters were collected. The skimmed liquid and bottle rinsings were blended with the centrate in the centrate tank. The volume of centrate was measured, the centrate was thoroughly mixed by recirculation with the slurry pump, and a sample was taken for measurement of solids content.

For the second pass through the centrifuge, the centrate was pumped back to the unrinsed feed tank; the centrate tank was rinsed with $\sim 2$ liters of water, and the rinsings were added to the feed tank. In those tests in which carrier precipitation ${ }^{3}$ of ${ }^{90} \mathrm{Sr}$ was tested, $250 \mathrm{ml}$ of a precipitant solution (identified in Table 6) was poured into the feed tank. Volume measurement, agitation, sampling, and measurement of the solids content were repeated for the slurry in the feed tank. The centrifugation operations then were repeated, typically with slower feed and flocculant flow rates than for the first pass. When the feed tank was empty, it was rinsed with $v 2$ liters of water, and the rinsings were fed to the centrifuge. After the second-pass skimming, the centrifuge was stopped.

\section{First Drying}

Drying operations were done in the centrifuge bowl dryer for most of the tests. After removing any excess liquid from the bowl and sampling the wet cake for analysis, the bowl was removed from the centrifuge and placed in the dryer. For the first drying, the sludge was heated at $\sim 140^{\circ} \mathrm{C}$ with a good off-gas 
sweep until the cake was dry, typically overnight. In a few tests the off-gases were bubbled through a trap containing $2 \mathrm{M}$ $\mathrm{NaOH}$ to measure possible ruthenium evolution. When drying was complete, the bowl was removed from the oven and cooled.

\section{Washes}

To wash the sludge, the bow1 containing dried sludge was placed into the centrifuge, and the cake was broken up mechanically. Then, 4 liters of water were jetted into the bowl to further break up the cake and wash down the inner wall. The contents of the bowl were agitated for 1 hour with an electric stirrer to reslurry the cake. With the stirrer removed, the centrifuge was started carefully, to ensure good balance with the full bowl. The cake was centrifuged for 10 minutes, and then the wash liquid was skimmed out of the bowl into a glass bottle. After skimming was completed, the centrifuge was stopped. The volume of the wash liquid was measured, a sample was taken for analysis, and the excess wash was discarded. For second and subsequent washes, the operations were repeated with 4 liters of fresh wash water. Typically, 3 washings were performed. Excess liquid was removed from the bowl after the finat wash.

\section{Second Drying}

For the second drying, the bowl containing washed sludge was removed from the centrifuge, placed in the dryer, and heated as before, until the cake was dry. After cooling, the washed, dried cake (product) was removed from the bowl mechanically. The product was pulverized, weighed, sampled for analysis, and stored for possible future use. The centrifuge bowl was cleaned in preparation for another test.

\section{Sand Fiztration}

Centrate from centrifugation operations was stored in the centrate tank and/or in 50-1iter polyethylene bottles, until needed for cesium-removal process steps ${ }^{3}$.(Module 3). Then, batches of 50 to 150 liters of centrate were passed through the sand filter for clarification. During sand filtration, the centrate was agitated with the slurry pump and transferred to the sand filter at $400 \mathrm{~m} 1 / \mathrm{min}$ with a bellows pump. Dilute flocculant solution (1 ppm) was pumped to the sand filter at $20 \mathrm{ml} / \mathrm{min}$ with another bellows pump. Filtrate was collected in the feed bottle for the cesium-removal process. When the centrate container was 
empty, it was rinsed with 2 liters of water, the rinsings were fed to the sand filter, and then the flocculant flow was stopped. At the end of the filtration, the filtrate was sampled for measurement of solids content. The sand filter was backwashed after each use.

\section{Process Variations}

In a few tests, parts of the procedure were altered to accommodate special conditions. For example, in Test 7, 100 liters of slurry were processed to study the effects of increased cake volume on the separation. The larger slurry volume required extra 50-liter storage bottles and additional manipulations; each centrifuge pass was divided into two parts to permit changing feed and centrate containers.

In Tests 9 and 11 , an extra pass through the centrifuge was made to evaluate a proposal to operate normally without flocculant and to recycle with flocculant any centrate with high solids content. During these tests, in a preliminary pass, slurry was fed to the centrifuge without flocculant, residual liquid was skimmed, and the centrifuge was stopped. The centrate was pumped back into the bow1 to reslurry the cake, and the reslurried material was transferred to the feed tank. Then, centrifugation operations were resumed with flocculant as with other tests.

Sludge was washed three times in all tests except Tests 3 and 7 . In Test 3 the sludge was washed five times to study the effect of additional washes. In Test 7 the double batch of sludge was washed six times because of the larger volume of sludge.

The rotary dryer (Figure 6) was evaluated with the second drying step in Test 11, and with both drying steps in Tests 12 and 13. Wet sludge cake was scraped from the centrifuge bow1 and placed in the hydraulic chamber of the dryer. After the sludge was dried, it was returned to the centrifuge bowl for reslurrying with wash water. After a second drying the product was pulverized and stored.

\section{Results}

Solids contents and specific gravities were determined for samples of the feed slurry, centrate, and centrate stream in each of the 13 tests. Typical data for a test are given in Table 7 . Specific gravities, calculated from volume and weight measurements, ranged from 1.18 to 1.30 and were correlated with solids contents of the liquids. 
TABLE 7

Typical Centrifuge Test Data (Test 6)

\begin{tabular}{|c|c|c|c|c|c|}
\hline & & First & $a 88$ & Secon & Pass \\
\hline & $\begin{array}{l}\text { Volume, } \\
\text { liters }\end{array}$ & $S p G$ & $\begin{array}{l}\text { Solids, } \\
\text { vol \% }\end{array}$ & $S p G$ & $\begin{array}{l}\text { Solids } \\
\text { vol \% }\end{array}$ \\
\hline Feed Slurry & & 1.27 & 3.0 & 1.21 & 0.2 \\
\hline Centrate Stream & 10 & 1.22 & 0.2 & 1.19 & 0.05 \\
\hline & 20 & 1.23 & 0.3 & 1.19 & 0.05 \\
\hline & 30 & 1.24 & 0.3 & 1.19 & 0.05 \\
\hline & 40 & 1.24 & 0.2 & 1.19 & 0.05 \\
\hline & 50 & 1.09 & 0.1 & 1.18 & 0.04 \\
\hline Centrate Tank & & 1.22 & 0.1 & 1.18 & 0.05 \\
\hline
\end{tabular}

Solids removal in the first centrifuge pass depended on the feed rate, the type of sludge, and the use of flocculant, as shown in Figure 8 . In the centrifuge tests, 50 to 97.5 vol $\%$ of solids in the feed slurries were separated in the first pass. For sludges from Tanks $12 \mathrm{H}$ and $13 \mathrm{H}$, the solids removal decreased with increasing feed rate; the solids removal was nearly independent of feed rate for Tank $5 \mathrm{~F}$ sludge. Tests without flocculant gave better separations than the tests with flocculant in two of the three comparisons made. In general, the first-pass separations behavior of the actual sludges was similar to that of simulated sludges (Table 3 ).

Cumulative solids removal after the second centrifuge pass is given in Table 8 for each of the 13 tests. In every test, the feed rate was $1.9 \mathrm{l} / \mathrm{min}$ for the second pass. The cumulative solids removal ranged from 90.0 to 99.2 vol $\%$. Solids contents of the centrates after two passes through the centrifuge ranged from 0.05 to 0.2 vol $\%$ and averaged 0.11 vol $\%$. These centrates were fed to the sand filter for further reduction of solids content.

For every batch of centrate passed through the sand filter, the filtrate had $<0.01$ vol $\%$ solids (the minimum detectable level). The sand-filter product was suitable for further processing to remove cesium by ion exchange. ${ }^{3}$ The sand-filter columns operated very reliably during the small-scale process studies.

Results of Test 7 showed that batch-size effects were unimportant. In this test the quantity of supernate was doubled, and four batches of sludge were blended to give a slurry with high solids content. 97.5 vol $\%$ solids removal was achieved in two passes. Measurements of solids in centrate stream samples 
showed no reduction in degree of separation as the cake increased in depth. Presumably, adequate centrifugal separation could have continued until the cake filled the bowl entirely; 200 to 300 liters of slurry could have been processed before the bowl would be full of sludge cake.

Tests 9 and 11 showed that material that has passed through the centrifuge can be reslurried and recycled. By adding flocculant during the recycle operation, good separations were obtained. Because other tests suggested that operating without flocculant would be satisfactory in most cases, Tests 9 and 11 demonstrated a method to handle the exceptions.

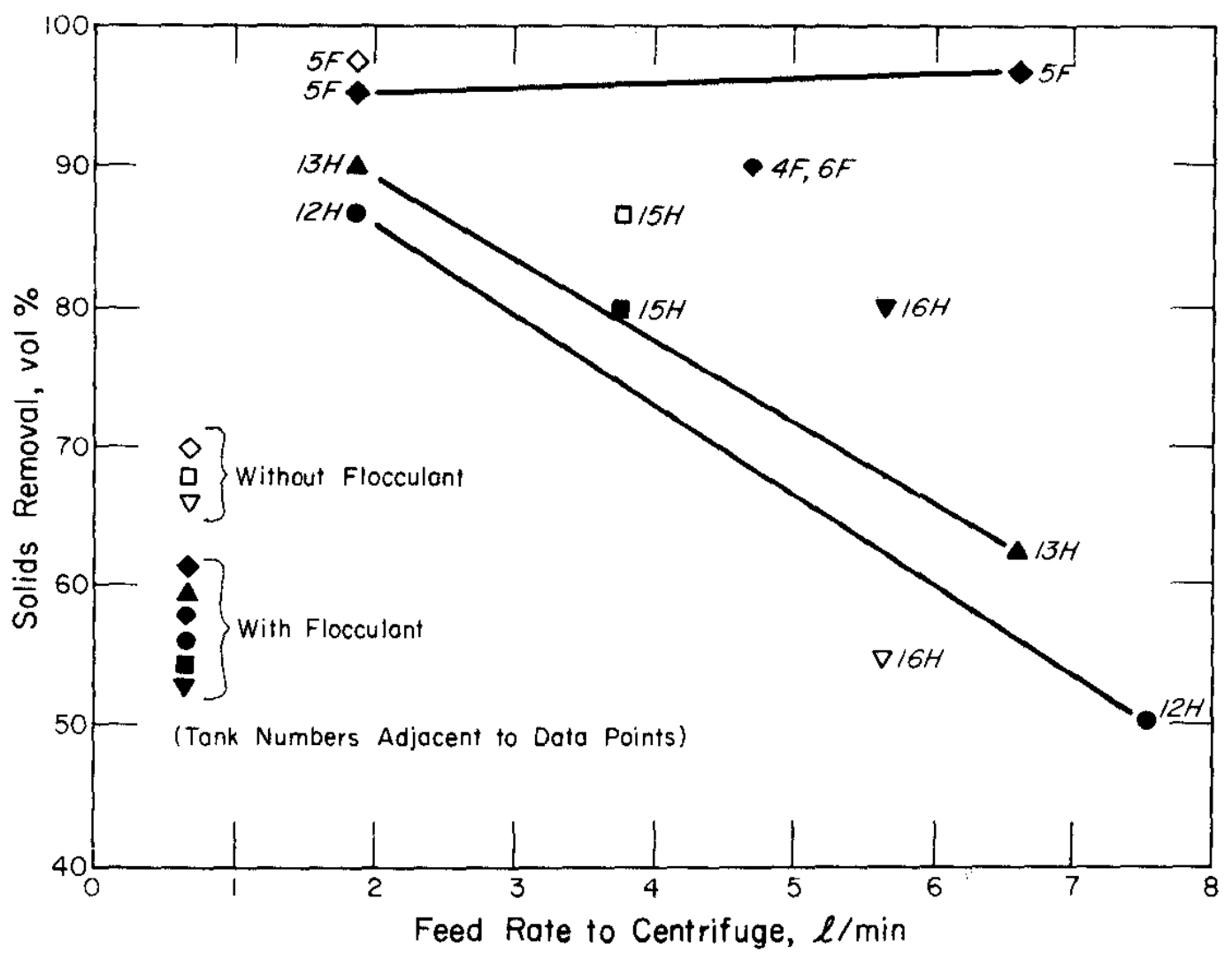

FIGURE 8. Solids Removal in First-Pass Centrifugation of SRP Waste Slurries 
TABLE 8

Centrifuge Test Results with Actual Waste Slurries, vol \%

\begin{tabular}{llllll} 
& \multicolumn{2}{l}{ Solids in Feed Slurry to } & & \multicolumn{2}{c}{ Comulative Solids Removal } \\
\cline { 5 - 6 } Test & Centrifuge & Sond Fizter & & First Pass & Second Pass \\
1 & 1.5 & 0.15 & $a$ & 90.0 \\
2 & 3 & 0.06 & 90 & 98.0 \\
3 & 4 & 0.15 & 62.5 & 96.3 \\
4 & 2 & 0.07 & 97.5 & 96.5 \\
5 & 2 & 0.07 & 95.5 & 96.5 \\
6 & 3 & 0.05 & 96.7 & 98.3 \\
7 & 4 & 0.10 & 90 & 97.5 \\
8 & 4 & 0.08 & 80 & 98.0 \\
9 & 6 & & $86.7^{b}$ & \\
& 5 & 0.05 & 96.7 & 99.2 \\
10 & 4 & 0.20 & 80 & 95.0 \\
11 & 4 & & $55^{b}$ & \\
& 2 & 0.08 & 82 & 98.2 \\
12 & 4 & 0.20 & 50 & 95.0 \\
13 & 3 & 0.15 & 86.7 & 95.0
\end{tabular}

Average

0.11

96.4

a. Not measured.

b. Reslurried after preliminary pass.

Drying and washing operations for the centrifuged sludge cake from each test are described in Table 9, together with the yield of washed, dried sludge powder from each test. Samples of wet cakes, wash liquids, and dried products were analyzed ${ }^{10}$ for $\mathrm{Na}^{+}, \mathrm{NO}_{3}{ }^{-}, \mathrm{NO}_{2}{ }^{-}, \mathrm{SO}_{4}{ }^{2-},{ }^{90} \mathrm{Sr}$, and ${ }^{134,137} \mathrm{Cs}$. The solids also were analyzed for alpha emitters and for other gamma emitters. The wash liquids were analyzed for $\mathrm{OH}^{-}, \mathrm{CO}_{3}{ }^{2-}$, and $\mathrm{Al}(\mathrm{OH})_{4}{ }^{-}$. Table 10 gives some typical analytical data showing the efficiency of the method of washing; as with the simulated sludges, the material balances are imperfect because of analytical uncertainties. One batch of washed, dried sludge product from each waste tank was analyzed for elemental composition. Chemical and radionuclide content of major species is given in Table 11. 


\section{TABLE 9}

Washed, Dried Sludges

$\begin{array}{cllr}\text { Test } & \text { Dryer } & \text { Washes } & \begin{array}{r}\text { Yiezd, } \\ \text { grams }\end{array} \\ 1 & \text { Bow1 } & 3 & 265 \\ 2 & \text { Bowl } & 3 & 513 \\ 3 & \text { Bowl } & 5 & 471 \\ 4 & \text { Bowl } & 3 & 596 \\ 5 & \text { Bowl } & 3 & 931 \\ 6 & \text { Bow1 } & 3 & 1,065 \\ 7 & \text { Bow1 } & 6 & 1,335 \\ 8 & \text { Bow1 } & 3 & 698 \\ 9 & \text { Bowl } & 3 & 914 \\ 10 & \text { Bowl } & 3 & 517 \\ 11 & \text { a } & 3 & 328 \\ 12 & \text { Rotary } & 3 & 264 \\ 13 & \text { Rotary } & 3 & 320\end{array}$

a. First Drying: Bowl Second Drying: Rotary

TABLE 10

Typical Analyses of Tank $15 \mathrm{H}$ Actual Sludges and Washes (Test 8 )

\begin{tabular}{|c|c|c|c|c|c|c|c|c|c|}
\hline & & $\mathrm{Na}^{+}$ & & & $\mathrm{NO}_{3}^{-}$ & & & ${ }^{1{ }^{7} \mathrm{Cs} \text { Activ }}$ & \\
\hline & Quantity & Cone & Moles & Groms & Cone & Moles & Grams & $\operatorname{Conc}^{a}$ & Total, dis/min \\
\hline $\begin{array}{l}\text { Unwashed } \\
\text { Sludge }\end{array}$ & $21800 \mathrm{~g}$ & 11.58 wt \% & 9.08 & 209 & 19.1 wt $\frac{8}{b}$ & 5.54 & 343 & $1.75 \times 10^{9}$ & $3.15 \times 10^{12}$ \\
\hline Washes: & & & & & & & & & \\
\hline First & 3.25 & $2.01 \mathrm{M}$ & 6.53 & 150 & $0.507 \mathrm{M}$ & 1.65 & 102 & $3.78 \times 10^{8}$ & $1.23 \times 10^{12}$ \\
\hline Second & 3.45 & $0.35 \mathrm{M}$ & 1.21 & 28 & $0.148 \mathrm{M}$ & 0.51 & 32 & $9.58 \times 10^{7}$ & $3.31 \times 10^{11}$ \\
\hline Third & 3.80 & $0.09 \mathrm{M}$ & $\underline{0.36}$ & $\underline{8}$ & $0.035 \mathrm{M}$ & $\underline{0.13}$ & 8 & $2.08 \times 10^{7}$ & $7.90 \times 10^{10}$ \\
\hline Total & 10.50 liters & & 8.10 & 186 & & 2.29 & 142 & & $1.64 \times 10^{12}$ \\
\hline $\begin{array}{l}\text { Product } \\
\text { Sludge }\end{array}$ & $698 \mathrm{~g}$ & $2.04 \mathrm{wt} g$ & 0.62 & 14 & 0.2 wt $\frac{0}{6}$ & 0.03 & 2 & $4.30 \times 10^{8}$ & $3.00 \times 10^{11}$ \\
\hline
\end{tabular}

a. dis/(min) (g) for sludges; dis/(min) (mI) for washes 
TABLE 11

Principal Components of Washed, Dried Sludges

$\begin{array}{llllll}\text { Tanks 4F,6F } & \text { Tank 5F } & \text { Tank 12H } & \text { Tank 13H } & \text { Tank 15H } & \text { Tank 16H } \\ \text { (Test 7) } & \text { (Test 6) } & \text { (Test 13) } & \text { (Test 3) } & \text { (Test 9) } & \text { (Test 11) }\end{array}$

A. Principal Metal Ions, wt \&

$\begin{array}{lr}\mathrm{Fe} & 32.77 \\ \mathrm{Al} & 2.28 \\ \mathrm{Mn} & 1.99 \\ \mathrm{U} & 9.22 \\ \mathrm{Na} & 2.95 \\ \mathrm{Sr} & 1.70^{\circ} \\ \mathrm{Ca} & 2.28 \\ \mathrm{Hg} & 0.65 \\ \mathrm{Ni} & 6.29\end{array}$

$\begin{array}{rr}28.90 & 4.49 \\ 1.57 & 30.16 \\ 5.83 & 1.69 \\ 10.81 & a \\ 5.66 & 1.03 \\ 1.29^{c} & b \\ 0.90 & 2.13 \\ 0.12 & 1.12 \\ 6.34 & 0.46\end{array}$

25.57

$5.29 \quad 13.91$

8.70

$18.75 \quad 16.61$

99

7.85

2.45

2.59

4.18

3.77

4.49

2.58

2.45

2.19

$3.50^{\circ}$

$1.80^{\circ}$

$b$

1.76

0.52

2.87

2.32

2.51

2.80

B. Principal

Anions, wt $\%$

$\begin{array}{lcccccc}\mathrm{NO}_{3}{ }^{-} & 0.12 & 1.16 & 0.42 & 0.31 & 0.19 & 0.32 \\ \mathrm{NO}_{2}{ }^{-} & 0.02 & 0.12 & 0.17 & 0.01 & 0.16 & 0.15 \\ \mathrm{SO}_{4}{ }^{2-} & <0.5 & <0.5 & <0.5 & <0.5 & <0.5 & <0.5 \\ \mathrm{PO}_{4}{ }^{3-} & 0.69^{c} & 0.32^{c} & b & 2.15^{c} & 2.87^{c} & b\end{array}$

C. Principal

Radionuclides, $\mathrm{mCi} / \mathrm{g}$

${ }^{90} \mathrm{Sr}$
${ }^{144} \mathrm{Ce}$
${ }^{106} \mathrm{Ru}$
$1{ }^{7} \mathrm{Cs}$
$1{ }^{54} \mathrm{Eu}$
$125 \mathrm{Sb}$
${ }^{60} \mathrm{Co}$

123.0
30.5
11.4
0.7
0.7
1.4
1.1

Gross $\alpha$

0.4

$\begin{array}{cc}177.5 & 41.4 \\ 1.5 & 17.4 \\ 1.3 & 1.7 \\ 0.9 & 0.05 \\ 0.6 & 0.5 \\ 0.9 & 0.3 \\ 1.1 & <0.01 \\ 0.1 & 0.7\end{array}$

30.

0.3

55.0

53.6

30.5

0.08

5.4

0.6

1.4

0.3

1.0

0.2

0.7

0.08

0.1

0.2

.4

0.06

0.4

0.1

1

0.01

0.3

0.04

0.2

0.06

0.02

0.1

0.15
a. None detected.
b. Not determined.
c. $\mathrm{Sr}_{3}\left(\mathrm{PO}_{4}\right)_{2}$ carrier added. 
Ruthenium volatility from sludge dried at $140^{\circ} \mathrm{C}$ was negligible. Traps for muthenium evolved during drying were analyzed for ${ }^{106} \mathrm{Ru}$, and none was detected. Also, the amount of ${ }^{106} \mathrm{Ru}$ measured in unwashed and washed sludges was approximately constant, showing that very little could have been lost by volatility.

Operation of the centrifuge bowl dryer was satisfactory for the 21 dryings for which it was used, although each drying required at least 16 hours. The rotary dryer was tested in 5 dryings, with mixed results. Dryings were rapid, in 2 hours or less, but in some cases difficulties were encountered with sludge adhering to rollers. This occurred only with some of the actual sludges and not with simulated sludges. Further development of the rotary dryer concept would be required for routine use.

CONCLUSIONS

The results of the small-scale process studies led to the following conclusions:

1. SIurries from SRP waste tanks can be separated adequately into sludge and supernate components by two stages of centrifugation. Further clarification of the supernate by sand filtration can remove almost all of the solids and provide salt solution suitable for cesium-removal process steps.

2. Centrifuge separations may be limited by mechanical effects such as improper balance or leveling of the centrifuge. Elimination of these effects may be more important to good separations than sludge properties or feed rate.

3. Solids removal in one stage of centrifugation was inversely proportional to slurry feed rate for sludges from Tanks $12 \mathrm{H}$ and $13 \mathrm{H}$. However, the separation for Tank $5 \mathrm{~F}$ sludge was nearly independent of feed rate.

4. After two stages of centrifugation, cumulative solids removal was large and nearly the same for all of the sludge types studied.

5. Batch size was not a significant factor in degree of separation attained.

6. Generally, good separations were obtained without flocculant. Flocculant proved to be only marginally useful in these tests. A method was demonstrated for recycling with flocculant, should poor separations without flocculant be encountered. On the basis of these results, routine use of flocculant in the conceptual process is not recommended. 
7. The washing and drying methods for sludges in the sma11-scale studies were generally satisfactory, although probably not suitable for a large-scale process.

8. The behavior of actual sludges in the centrifugation tests was quite similar to that of simulated sludges. Apparently both sludges have the same hydraulic and mechanical properties responsible for good separations. This similarity suggests that engineering development of the sludge-supernate separation module can proceed with simulated sludges, with a high degree of confidence that results will be appropriate for actual SRP waste.

\section{ACKNOWLEDGMENTS}

R. M. Galloway of the SRL Separations Engineering Division made preliminary development studies that established the principal centrifugation and sand-filtration operating parameters, and he also provided pilot-scale quantities of the simulated waste slurries used in some of the tests reported here. Actual SRP waste sludges and supernates were obtained with the cooperation of the SRP Separations Technology and Separations Departments. The SRL High-Level Caves design group and operating group mođified the equipment for remote operation and performed the tests with actual wastes in shielded-cell facilities. Samples were analyzed by the Analytical Chemistry Division of SRL. 


\section{REFERENCES}

1. R. M. Wallace, W. H. Hale, R. F. Bradley, H. L. Hul1, J. A. Kelley, J. A. Stone, and G. H. Thompson. "Solid Forms for Savannah River Plant Radioactive Wastes." Advances in Chemistry Series 153, 9 (1976).

2. A. J. Hil1, Jr. Removal of Sludge from High Activity Waste Tanks. USAEC Report DP-1093, E. I. du Pont de Nemours and Company, Savannah River Laboratory, Aiken, S. C. (1967).

3. J. R. Wiley. Decontomination of SRP Waste Supermate. ERDA Report DP-1436, E. I. du Pont de Nemours and Company, Savannah River Laboratory, Aiken, S. C. (1976).

4. J. A. Stone. Evaluation of Concrete as a Matrix for Solidification of Savannah River Plont Waste. ERDA Report DP-1448, E. I. du Pont de Nemours and Company, Savannah River Laboratory, Aiken, S. C. (to be issued).

5. J. A. Kelley. Evaluation of Glass as a Matrix for Solidification of Savannah River Plant Waste. Nonradioactive and Tracer Studies. ERDA Report DP-1382, E. I. du Pont de Nemours and Company, Savannah River Laboratory, Aiken, S. C. $(1975)$.

6. J. A. Kelley. Evaluation of Glass as a Matrix for Solidification of Savannah River Plant Waste. Radioactive Studies. ERDA Report DP-1397, E. I, du Pont de Nemours and Company, Savannah River Laboratory, Aiken, S. C. (1975).

7. C. B. Goodlett. "Concentration of Aqueous Radioactive Waste with Wiped-Film Evaporators." Chem. Eng. Progr. 72, 63 (1976).

8. J. A. Stone, J. A. Kelley, and T. S. McMillan. Scompling and Analyses of SRP High-Level Waste Sludges. ERDA Report DP-1399, E. I. du Pont de Nemours and Company, Savannah River Laboratory, Aiken, S. C. (1976).

9. R. S. Ondrejcin. Chemical Compositions of Supermates Stored in SRP High Level Waste Tanks. USAEC Report DP-1347, E. I, du Pont de Nemours, Savannah River Laboratory, Aiken, S. C. (1974).

10. L. W. Gray and R. S. Ondrejcin. "Chemical Characterization of SRP Waste Tank Sludges and Supernates." 8th Conference on Analytical Chemistry in Nuclear Tecmology, Gatiinburg, $T N$, October 22-24, 1974. USAEC Report CONF-741042-1 (1974). 